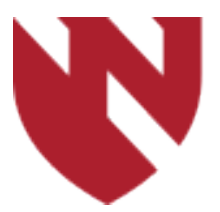

December 2019

\title{
Necrotizing Enterocolitis following Gastroschisis Repair: An Update
}

\author{
Rachel K. Schlueter \\ University of Nebraska Medical Center \\ Shahab F. Abdessalam \\ University of Nebraska Medical Center \\ Stephen C. Raynor \\ University of Nebraska Medical Center \\ Robert A. Cusick \\ University of Nebraska Medical Center
}

Tell us how you used this information in this short survey.

Follow this and additional works at: https://digitalcommons.unmc.edu/gmerj

Part of the Higher Education Commons, Pediatrics Commons, and the Surgery Commons

\section{Recommended Citation}

Schlueter, R. K., Abdessalam, S. F., Raynor, S. C., , Cusick, R. A. Necrotizing Enterocolitis following Gastroschisis Repair: An Update. Graduate Medical Education Research Journal. 2019 Dec 13; 1(1). https://digitalcommons.unmc.edu/gmerj/vol1/iss1/5 


\title{
Necrotizing Enterocolitis following Gastroschisis Repair: An Update
}

\begin{abstract}
Purpose:

Necrotizing enterocolitis (NEC) is a known complication of gastroschisis with an incidence above the expected rate in the neonatal population. While many physicians today are aware of this association, the last publication to explore this association in detail and identify possible risk factors of NEC in gastroschisis patients was published over twenty years ago. From our large database of patients with gastroschisis managed by a single group of pediatric surgeons, we reviewed our experience and the recent literature to update what is known about gastroschisis and NEC.
\end{abstract}

Methods:

From 2001 to 2017, a gastroschisis registry was maintained. Data from 218 gastroschisis patients were reviewed. Patient demographics and hospital course were reviewed. Patients with confirmed NEC were compared to those without NEC.

Results:

Two hundred eighteen patients were born with gastroschisis during the time frame of this study. We observed a $5 \%$ rate (11 of 218 ) of NEC. Five patients (45\%) developed recurring NEC and 4 patients (36\%) were readmitted for NEC development following initial discharge. Variables associated with NEC included low gestational age $(P=0.016)$ and low birth weight $(P=0.003)$. Patients born prior to 37 weeks gestation had a 4.8 times greater risk of developing NEC than those born at term. Rates of IUGR were not statistically different between NEC and non-NEC patients. The method of delivery (cesarean vs vaginal), use of a silo, and form of nutrition were not significantly associated with NEC development.

\section{Conclusions:}

The overall incidence of NEC has decreased compared to earlier reports. NEC does complicate the hospital course for patients, significantly increasing duration of in-hospital treatment. NEC in gastroschisis differs in comparison to traditional NEC, presenting later in life. Risk factors identified include low gestational age and low birth weight. Avoiding elective preterm deliveries may decrease the rate of NEC in gastroschisis.

\section{Keywords}

gastroschisis

\section{Creative Commons License}

\section{(c) (i) $\Theta$}

This work is licensed under a Creative Commons Attribution-Noncommercial-No Derivative Works 4.0 License. 


\section{Necrotizing Enterocolitis Following Gastroschisis Repair: An Update}

Rachel K. Schlueter ${ }^{1}$, Shahab F. Abdessalam², Stephen C. Raynor ${ }^{2}$, Robert A. Cusick ${ }^{2}$

${ }^{1}$ University of Nebraska Medical Center-Creighton University Medical Center-Children's Hospital \& Medical Center, Joint Pediatric Residency Training Program

${ }^{2}$ University of Nebraska Medical Center, Department of Pediatric Surgery

https://doi.org/10.32873/unmc.dc.gmerj.1.1.005

\section{Abstract}

Introduction: Necrotizing enterocolitis (NEC) is a known complication of gastroschisis with an incidence above the expected rate in the neonatal population. While many physicians today are aware of this association, the last publication to explore this association in detail and identify possible risk factors of NEC in gastroschisis patients was published over twenty years ago. From our large database of patients with gastroschisis, managed by a single group of pediatric surgeons, we reviewed our experience and the recent literature to update what is known about gastroschisis and NEC.

Methods: From 2001 to 2017, a gastroschisis registry was maintained. Data from 218 gastroschisis patients were reviewed. Patient demographics and hospital course were reviewed. Patients with confirmed NEC were compared to those without NEC.

Results: Two hundred eighteen patients were born with gastroschisis during the time frame of this study. We observed a $5 \%$ rate (11 of 218 ) of NEC. Five patients (45\%) developed recurring NEC and 4 patients $(36 \%)$ were readmitted for NEC development following initial discharge. Variables associated with NEC included low gestational age $(\mathrm{P}=0.016)$ and low birth weight $(\mathrm{P}=0.003)$. Patients born prior to 37 weeks gestation had a 4.8 times greater risk of developing NEC than those born at term. Rates of intrauterine growth restriction (IUGR) were not statistically different between NEC and non-NEC patients. The method of delivery (cesarean vs vaginal), use of a silo, and form of nutrition were not significantly associated with NEC development.

Conclusions: The overall incidence of NEC, based on our data, has decreased compared to earlier reports. NEC does complicate the hospital course for patients, significantly increasing duration of in-hospital treatment. NEC in gastroschisis differs in comparison to traditional NEC, presenting later in life. Risk factors identified include low gestational age and low birth weight. Avoiding elective preterm deliveries may decrease the rate of NEC in gastroschisis.

\section{Introduction}

Gastroschisis is a congenital right-sided paraumbilical defect allowing protrusion of intestines and other abdominal viscera out of the abdominal cavity, occurring in approximately 1 in 4000 live births ${ }^{1}$ and has increased by about $6 \%$ every two years for reasons unknown. ${ }^{2}$ Necrotizing enterocolitis (NEC) is a bacterial infection of the intestine, primarily observed in pre-term and small for gestational age (SGA) babies. ${ }^{3}$ The reported rate of necrotizing enterocolitis in gastroschisis patients has been quite variable in previous studies. ${ }^{4-16}$ While many physicians today are aware of the association of NEC in gastroschisis patients, the last publication to explore this association in detail and identify possible risk factors of NEC in gastroschisis patients was published over twenty years ago. ${ }^{4}$ We examined our experience with gastroschisis to identify risk factors for necrotizing enterocolitis in this patient population.

\section{Materials and Methods}

Patient Population and Data Collection: From 2001 to 2017, a gastroschisis registry was prospectively maintained at Children's Hospital and Medical Center, the University of Nebraska Medical Center, and Creighton University Medical Center (Omaha, NE). Patient demographics, surgical details, postoperative infections and complications, and length of stay were reviewed. Patients with confirmed NEC were compared to those without NEC. This study was approved by the University of Nebraska Medical Center- Joint Pediatric Institutional Review Board (\#44509-EP).

Definitions: The diagnosis of necrotizing enterocolitis was made using Bell's classification of radiographic and clinical findings (Table 1). Clinical findings of NEC included abdominal distention, hematochezia, and hemodynamic instability. Radiographic findings included pneumatosis intestinalis and portal venous gas. Prematurity was defined as a gestational age less than 37 weeks. Intrauterine growth restriction (IUGR) was defined as a birth weight at or below the 10th percentile for gestational age.

\section{Table 1.}

Modified Bell's Criteria were utilized to assist with staging NEC in our study.

\begin{tabular}{|c|c|c|c|c|}
\hline Stage & Systemic signs & Abdominal signs & Radiographic signs & Treatment \\
\hline $\begin{array}{l}\text { IA } \\
\text { Suspected }\end{array}$ & $\begin{array}{l}\text { Temp instability } \\
\text { Apnea } \\
\text { Bradycardia } \\
\text { Lethargy }\end{array}$ & $\begin{array}{l}\text { Gastric retention } \\
\text { Abd distention } \\
\text { Emesis } \\
\text { Heme + stool }\end{array}$ & $\begin{array}{l}\text { Mild ileus } \\
\text { Intestinal dilation }\end{array}$ & $\begin{array}{l}\text { NPO } \\
\text { Abx } x 3 \text { days }\end{array}$ \\
\hline $\begin{array}{l}\text { IB } \\
\text { Suspected }\end{array}$ & Same as IA & Grossly bloody stool & Same as IA & Same as IA \\
\hline IIA & Same as IA & $\begin{array}{l}\text { Same as IB }+ \\
\text { Absent bowel sounds } \\
\pm \text { abdominal } \\
\text { tenderness }\end{array}$ & $\begin{array}{l}\text { Intestinal dilation } \\
\text { Ileus } \\
\text { Pneumatosis } \\
\text { intestinalis }\end{array}$ & $\begin{array}{l}\text { NPO } \\
\text { Abx x 7-10 days }\end{array}$ \\
\hline IIB & $\begin{array}{l}\text { Same as IA + } \\
\text { Metabolic acidosis } \\
\text { Thrombocytopenia }\end{array}$ & $\begin{array}{l}\text { Same as IIA + } \\
\text { Abdominal } \\
\text { tenderness } \\
\pm \text { abdominal cellulitis } \\
\text { or RLQ mass }\end{array}$ & Same as IIA + ascites & $\begin{array}{l}\text { NPO } \\
\text { Abx } x 14 \text { days }\end{array}$ \\
\hline $\begin{array}{l}\text { IIIA } \\
\text { Intact bowel }\end{array}$ & $\begin{array}{l}\text { Same as IIB + } \\
\text { Hypotension } \\
\text { Bradycardia } \\
\text { Severe apnea } \\
\text { DIC } \\
\text { neutropenia }\end{array}$ & $\begin{array}{l}\text { Same as IIB } \\
\text { Peritonitis } \\
\text { Abdominal distention }\end{array}$ & Same as IIB & $\begin{array}{l}\text { NPO } \\
\text { Abx } x 14 \text { days } \\
\text { Fluid resuscitation } \\
\text { Inotropic support } \\
\text { Ventilator therapy } \\
\text { Paracentesis }\end{array}$ \\
\hline $\begin{array}{l}\text { IIIB } \\
\text { Perforated } \\
\text { bowel }\end{array}$ & Same as IIIA & Same as IIIA & $\begin{array}{l}\text { Same as IIIA + } \\
\text { Pneumoperitoneum }\end{array}$ & $\begin{array}{l}\text { Same as IIla + } \\
\text { Surgery }\end{array}$ \\
\hline
\end{tabular}


Statistical Analysis: Results were expressed as mean $\pm \mathrm{SD}$ or median and interquartile range as appropriate. Relative risks were also assessed. Analysis was performed using the Mann-Whitney test for continuous data and the Fisher's exact test for categorical data. A p-value of less than 0.05 was considered statistically significant.

\section{Results}

Two hundred eighteen patients were born with gastroschisis during the time frame of this study. The average gestational age was 35.7 weeks with the average birth weight of 2455 grams. One hundred forty-six (67\%) were born via cesarean section. Thirty-three percent ( 71 of 218 ) of patients were carried to term with the remaining patients delivered prior to 37 weeks gestation. Patients were kept on the ventilator for an average of 5.6 days (median=2). Silos were used on $45 \%$ (98 of 218) of patients for an average of 7.2 days. The average length of stay was 55.2 days $($ median $=36.5)$ (Table 2).

We observed a $5 \%$ rate (11 of 218 ) of NEC. Five patients ( $45 \%$ of NEC patients) developed recurring NEC and 4 patients (36\% of NEC patients) were re-admitted for NEC development following initial discharge (Tables $3 \& 4$ ). Variables associated with NEC included low gestational age (34.3 weeks vs 35.8 weeks, $\mathrm{P}=0.016)$ and low birth weight $(\mathrm{P}=0.003)$. Patients born prior to 37 weeks gestation had a 4.8 times greater risk of developing NEC than those born at term. Rates of IUGR were not statistically different between NEC and non-NEC patients. The method of delivery (cesarean vs vaginal), use of a silo, and form of nutrition were not significantly associated with NEC development. NEC developed on a median of 65 days of life. Infants who developed

\section{Table 2.}

Demographics of the total patient population identify an average population of late pre-term infants with a higher-than-normal rate of IUGR.

\begin{tabular}{ll}
$\mathbf{N = 2 1 8}$ & $\begin{array}{l}\text { Mean } \mathbf{E S D} \text { or number (\%) } \\
\text { or range }\end{array}$ \\
\hline Sex & $\begin{array}{l}55 \% \text { Male } \\
45 \% \text { Female }\end{array}$ \\
\hline Gestational age & $\begin{array}{l}35.69 \pm 2.00 \text { weeks } \\
\text { Range: } 28-40 \text { weeks }\end{array}$ \\
Carried to term & $32.6 \%$ \\
Spontaneous labor & $46 \%$ \\
\hline Birth weight & $2455.0 \pm 531.8 \mathrm{~g}$ \\
& Range: $1120-4200 \mathrm{~g}$ \\
\hline IUGR Rate & $18.4 \%$ IUGR \\
\hline Type of delivery & $67 \%$ Cesarean \\
& $33 \%$ Vaginal \\
\hline
\end{tabular}

NEC stayed a median of 69 days longer than patients who did not develop NEC (104 days vs 35 days, $\mathrm{P}=0.014$ ) (Tables $3 \& 4$ ).

\section{Discussion}

The incidence of gastroschisis is roughly 1 in 4,000 live births and appears to increase with a $6 \%$ rise every two years for reasons unknown. ${ }^{1,2,17-21}$ Worldwide, the survival rate of infants born with gastroschisis has also improved greatly. ${ }^{22,23}$ One of the known complications of gastroschisis is necrotizing enterocolitis. Although numerous reports of gastroschisis have identified the rate of NEC in gastroschisis, the last series to discuss this complication in detail was published over twenty years ago. . $-2,4-6,9,11-16,24^{\text {. From our series }}$ of patients with gastroschisis, we reviewed our experience and the recent literature to update what is known about gastroschisis and NEC.

NEC is primarily a disease of very low birth weight, pre-term infants, affecting $10 \%$ of infants born weighing less than 1500 grams and resulting in high rates of morbidity and mortality in neonatal intensive care units. ${ }^{12,25}$ Traditional NEC occurs by the second or third week of life. ${ }^{26-28} \mathrm{NEC}$ in gastroschisis presents less traditionally. Gastroschisis patients were diagnosed with NEC much later, with a median day of diagnosis of 65 days of life. Additionally, patients that developed NEC generally weighed more than 1500 grams. Necrotizing enterocolitis is typically treated with gut rest, antibiotics, and, if needed, surgery. Similar methods of treatment were seen in our NEC patients.

Among our NEC patients, only one (9\%) required surgical intervention. Our high rate of successful conservative management is unique in comparison to the general neonatal NEC population, which typically requires much higher rates of surgical intervention. ${ }^{26-28}$ Fullerton et al observed a $24 \%$ (49 of 204) rate of surgical intervention among gastroschisis patients with NEC12. Fullerton et al identified a higher mortality rate among surgical NEC patients compared to those conservatively managed $(12.2 \%$ vs $3.9 \%$ ). These findings suggest a different, less severe clinical course of NEC in gastroschisis compared to NEC among very low birth weight neonates. Fullerton et al suggested this fact supports the view that NEC is an "umbrella diagnosis" representing variant underlying pathologies, stating prevention and treatment must be tailored on a patientto-patient basis. Our study also experienced only one mortality, unlike the high mortality

\section{Table 3.}

Gastroschisis patients who developed necrotizing enterocolitis were compared to gastroschisis patients who did not develop necrotizing enterocolitis and data were compared using the MannWhitney test for continuous data and the Fisher's Exact test for categorical data.

\begin{tabular}{|c|c|c|c|}
\hline & NEC Group n=11 & Non-NEC Group n=207 & $\mathbf{P}$ \\
\hline Sex & & & 0.352 \\
\hline Male & $8(73 \%)$ & $112(54 \%)$ & \\
\hline Female & $3(27 \%)$ & $95(46 \%)$ & \\
\hline Gestational age & $34.3 \pm 2.00$ weeks & 35.8 weeks & 0.016 \\
\hline Birth weight & $\begin{array}{l}1955 \pm 299.0 \mathrm{~g} \\
(1451 \text { to } 2435 \mathrm{~g})\end{array}$ & $\begin{array}{l}2479 \pm 422.2 \mathrm{~g} \\
(1120 \text { to } 4200)\end{array}$ & 0.003 \\
\hline IUGR & $4(36 \%)$ & $36(17.4 \%)$ & 0.121 \\
\hline Delivery Method & & & 1.000 \\
\hline Cesarean Section & $7(64 \%)$ & $138(67 \%)$ & \\
\hline Vaginal Delivery & $4(36 \%)$ & $69(33 \%)$ & \\
\hline Spontaneous Labor & $36 \%$ Yes & $46 \%$ Yes & 0.758 \\
\hline Carried to term & & & 0.108 \\
\hline Yes & $1(9 \%)$ & $70(34 \%)$ & \\
\hline No & $10(91 \%)$ & $137(66 \%)$ & \\
\hline Silo & & & 0.228 \\
\hline Yes & $7(64 \%)$ & $91(44 \%)$ & \\
\hline No & $4(36 \%)$ & $116(56 \%)$ & \\
\hline $\begin{array}{l}\text { Mean Length } \\
\text { Range }\end{array}$ & $\begin{array}{c}5.9 \pm 2.0 \text { days } \\
(2-8 \text { days })\end{array}$ & $\begin{array}{c}7.3 \pm 3.1 \text { days } \\
(3-15 d)\end{array}$ & 0.130 \\
\hline Ventilator Days & $2(\mathrm{Q} 1, \mathrm{Q} 3=2,6)$ & $2(\mathrm{Q} 1, \mathrm{Q} 3=1,6)$ & 0.544 \\
\hline Length of Stay & 104 days $(Q 1, Q 3=56,114)$ & 35 days $(\mathrm{Q} 1, \mathrm{Q} 3=26,56)$ & 0.014 \\
\hline
\end{tabular}


Table 4.

Data on demographics and management of each patient who later developed necrotizing enterocolitis area included below.

\begin{tabular}{|c|c|c|c|c|c|c|c|c|c|c|c|}
\hline \multicolumn{7}{|c|}{ Demographics } & \multicolumn{5}{|c|}{ Diagnosis and Treatment } \\
\hline & $\begin{array}{c}\text { EGA } \\
\text { (weeks) }\end{array}$ & $\begin{array}{l}\text { Birth } \\
\text { Weight } \\
\text { (g) }\end{array}$ & Silo? & $\begin{array}{l}\text { DOL } \\
\text { Diagnosed } \\
\text { (days) }\end{array}$ & $\begin{array}{l}\text { Post } \\
\text { Closure } \\
\text { Day }\end{array}$ & $\begin{array}{c}\text { LOS } \\
\text { (days) }\end{array}$ & How diagnosed & $\begin{array}{l}\text { Bell's } \\
\text { Stage }\end{array}$ & $\begin{array}{l}\text { Antibiotics } \\
\text { Prescribed }\end{array}$ & $\begin{array}{l}\text { Length } \\
\text { Antibiotics } \\
\text { Prescribed }\end{array}$ & Surgery \\
\hline 1 & 35 & 2160 & Yes & 94 & 88 & 80 & $\begin{array}{l}\text { Bloody stool } \\
\text { Pneumatosis } \\
\text { Temp. instability } \\
\text { Bradycardia } \\
\text { Dilated bowel loops }\end{array}$ & II a & $\begin{array}{l}\text { Ampicillin, } \\
\text { Gentamicin, } \\
\text { Flagyl }\end{array}$ & $8 d$ & \\
\hline 2 & 32 & 1780 & Yes & 63 & 58 & 54 & $\begin{array}{l}\text { Pneumatosis } \\
\text { Distended bowel } \\
\text { Portal Air } \\
\text { Bloody stool } \\
\text { Abdominal distension }\end{array}$ & II a & $\begin{array}{l}\text { Ampicillin, } \\
\text { Gentamicin, } \\
\text { Clendamycin }\end{array}$ & $8 d$ & \\
\hline 3 & 36 & 1724 & Yes & $54 \& 75$ & $47 \& 68$ & 114 & $\begin{array}{l}\text { Pneumatosis } \\
\text { Distended bowel } \\
\text { Portal Air } \\
\text { Ascites }\end{array}$ & III a & $\begin{array}{l}\text { Zosyn, } \\
\text { Gentamicin } \\
\text { Gentamicin, } \\
\text { Zosyn, Flagyl }\end{array}$ & $\begin{array}{l}10 \mathrm{~d} \\
10 \mathrm{~d}\end{array}$ & \\
\hline 4 & 37 & 2435 & No & 40 & 40 & 114 & $\begin{array}{l}\text { Abdominal distension } \\
\text { Portal venous gas } \\
\text { Fluid collection }\end{array}$ & III a & $\begin{array}{l}\text { Vancomycin, } \\
\text { Gentamicin, } \\
\text { Zosyn }\end{array}$ & $\begin{array}{l}14 d, 11 d, \\
14 d\end{array}$ & Yes \\
\hline 5 & 36 & 2160 & Yes & $69 \& 87$ & $61 \& 79$ & 145 & $\begin{array}{l}\text { Pneumatosis } \\
\text { Bloody stool } \\
\text { Distended Bowel }\end{array}$ & II a & $\begin{array}{l}\text { Zosyn } \\
\text { Zosyn, } \\
\text { Gentamicin, } \\
\text { Flagyl }\end{array}$ & $\begin{array}{l}7 \mathrm{~d} \\
7 \mathrm{~d}, 7 \mathrm{~d} \\
7+10 \mathrm{~d}\end{array}$ & \\
\hline 6 & 35 & 2255 & No & 73 & 73 & 25 & $\begin{array}{l}\text { Pneumatosis } \\
\text { Bloody stool } \\
\text { Intestinal ischemia }\end{array}$ & II a & $\begin{array}{l}\text { Ampicillin, } \\
\text { Gentamicin, } \\
\text { Flagyl }\end{array}$ & $14 d$ & \\
\hline 7 & 31 & 1451 & Yes & 15 & 13 & 199 & $\begin{array}{l}\text { Pneumatosis } \\
\text { Temp. instability } \\
\text { Loose stool } \\
\text { Lethargy }\end{array}$ & II b & $\begin{array}{l}\text { Gentamicin, } \\
\text { Zosyn, } \\
\text { Vancomycin }\end{array}$ & $21 d, 3 d, 9 d$ & \\
\hline 8 & 34 & 1990 & Yes & $\begin{array}{l}42,62 \\
\& 76\end{array}$ & $\begin{array}{c}35,55 \\
\& 69\end{array}$ & 104 & $\begin{array}{l}\text { Pneumatosis } \\
\text { Temp. instability } \\
\text { Lethargy } \\
\text { Abdominal distension } \\
\text { Bilious emesis }\end{array}$ & II a & $\begin{array}{l}\text { Zosyn } \\
\text { Vancomycin, } \\
\text { Zosyn }\end{array}$ & $\begin{array}{l}11 d \\
7 d\end{array}$ & \\
\hline 9 & 36 & 2390 & Yes & $65 \& 79$ & $59 \& 73$ & 107 & $\begin{array}{l}\text { Feeding intolerance } \\
\text { Pneumatosis } \\
\text { Bloody stool }\end{array}$ & II a & Zosyn & $10 \mathrm{~d}, 7 \mathrm{~d}$ & \\
\hline 10 & 31 & 1700 & No & $52 \& 76$ & $52 \& 76$ & 36 & $\begin{array}{l}\text { Pneumatosis } \\
\text { Abdominal distension } \\
\text { Hematochezia }\end{array}$ & II a & $\begin{array}{l}\text { Flagyl } \\
\text { Zosyn }\end{array}$ & $\begin{array}{l}7 d \\
10 d\end{array}$ & \\
\hline 11 & 34 & 1900 & No & 41 & 41 & 58 & $\begin{array}{l}\text { Pneumatosis } \\
\text { Temp. instability } \\
\text { Lethargy }\end{array}$ & II a & $\begin{array}{l}\text { Zosyn } \\
\text { Vancomycin }\end{array}$ & $7 d$ & \\
\hline Mean & 34 & 1990 & & 62.5 & 58.1 & 89.8 & & & & & \\
\hline
\end{tabular}

rate seen in pre-term infants with NEC and gastroschisis in prior studies. ${ }^{8}$

The last study to explore the association of NEC and gastroschisis in detail was Oldham's study, published over 20 years ago. ${ }^{4}$ Compared to his study, we experienced a relatively low rate of NEC $(18.5 \%$ vs $5 \%$, $10 / 54$ vs $11 / 218$, respectively). An additional 13 patients in the former study had soft signs of NEC, making the difference even greater. Mortality in Oldham's series was $20 \%$ overall compared to the single death in our series. These differences are likely due to advances in perinatal, neonatal, and surgical care of this complicated patient population. Further, our current series carefully reviewed each NEC case and assigned a Bell's stage to ensure the accuracy of diagnosis. Our rate of NEC in this study was comparable to that rate found in several more recent studies, ranging from $0-15 \%^{5-16}$ (Table 5).

Patients in Oldham's study were diagnosed with NEC on an average of 52 days of life, comparable to our study (62.5 days, median 65 days). Both studies documented that patients were readmitted due to development of NEC (Oldham: 3/10, Current Study: 4/11). Fifty-four percent (29 of 54) of patients in Oldham's study vs. 55\% (120/218) in our study underwent primary closures of their abdominal wall defect. Both reported recurring NEC (Oldham: 38\%, Current Study: $45 \%)^{4}$

Lao et al looked at 2490 gastroschisis patients, with a NEC rate of $5 \%$, which is comparable to our experience $(5 \%) .{ }^{4}$ The median length of stay in Lao's study was 35 days, as opposed to our 104 day median length of stay. Forty percent of NEC patients were born prior to 37 weeks gestation in Lao's study, while the number climbed to $91 \%$ in our study. Lao et al identified potential modifiable factors 
impacting mortality to include large bowel resection and the presence of bacterial sepsis, both factors associated with NEC. The clinical impact of NEC is consistent in both studies, emphasizing the importance of identifying modifiable factors to reduce the incidence of NEC.

Older reports of gastroschisis have suggested early delivery may be associated with better outcomes. ${ }^{29-31}$ This remains controversial. More recent studies show worse outcomes with early delivery, including an increased risk of infectious complications ${ }^{32}$ and poorer long-term neurodevelopmental outcomes. ${ }^{33}$ Maramreddy et al found gastroschisis patients delivered prior to 37 weeks gestation had a 14 times greater risk of morbidities than patients carried to term. ${ }^{6}$ Soares et al also did not support pre-term delivery of fetuses with gastroschisis, finding no benefit to achieving full feeds faster. ${ }^{1}$ Huang et al found that gastroschisis pregnancies carried to term led to earlier defect closures, and shorter times to full feeds, suggesting that the benefits of early delivery cannot be substantiated. ${ }^{34}$ Gorra et al found that pre-term gastroschisis patients experienced poorer developmental outcomes. ${ }^{33}$ Pre-term, low birth weight infants have been identified as being at increased risk of infection. ${ }^{32}$ Patients who developed NEC were on average 1.5 weeks younger at birth and weighed 484 grams less. Infants not carried to term were found to be 4.8 times more likely to develop NEC than infants carried to term. This raises concern about an increased risk of NEC with scheduled preterm delivery of patients with gastroschisis.

Prior publications have identified the protective nature of human breast milk against late onset sepsis, NEC, and death. ${ }^{9,35-36}$ The etiology of this may be associated with more swift weight gain and reduced feeding intolerance associated with breastfed infants. Unlike these studies, our study found no statistically significant difference in the rate of NEC due to form of nutrition. The practice of initiating trophic feeds within the first 72 hours may also promote digestive tolerance, allowing faster volume increases and helps the neonate achieve full feeds earlier. ${ }^{37}$

The gastroschisis patients whom develop NEC tend to have a much more complicated medical course, resulting in a longer length of stay on average. NEC can also occur after discharge home, requiring readmission of 4 of our patients. Because NEC presents itself very differently in the gastroschisis population as compared to the general neonatal population, it is vital for neonatologists, surgeons, and general pediatricians to remain vigilant to

Table 5.

Literature review of relevant studies reviewing this topic are summarized below.

\begin{tabular}{|c|c|c|c|c|c|}
\hline Author & Date & Patients & $\begin{array}{c}\text { NEC } \\
\text { Patients }\end{array}$ & $\begin{array}{l}\text { Rate of } \\
\text { NEC }\end{array}$ & Conclusion \\
\hline Oldham & 1988 & 54 & 10 & $18.5 \%$ & $\begin{array}{l}\text { High incidence of NEC: } 30 \% \text { readmitted for NEC } \\
(3 \text { of } 10)\end{array}$ \\
\hline Jayanthi & 1998 & 54 & 8 & $15 \%$ & $\begin{array}{l}\text { Unpasteurized, expressed breast milk may } \\
\text { protect from NEC }\end{array}$ \\
\hline Snyder & 1999 & 185 & 8 & $4 \%$ & Increased mortality seen in NEC patients (3 of 8 ) \\
\hline Eggick & 2006 & 66 & 6 & $9 \%$ & $\begin{array}{l}\text { No difference seen between NEC and No-NEC } \\
\text { patients in regards to birth weight or gestational } \\
\text { age }\end{array}$ \\
\hline Charlesworth & 2007 & 110 & 7 & $6.36 \%$ & $\begin{array}{l}\text { NEC was more frequent in pre-term }(P=0.13) \\
\text { and infants larger than } 2 \mathrm{~kg}(P=0.15)\end{array}$ \\
\hline Maramreddy & 2009 & 36 & 3 & $8.3 \%$ & No NEC found in term infants \\
\hline Lao & 2010 & 2490 & 127 & $5.1 \%$ & $5 \%$ NEC according to PHIS database \\
\hline Kassa & 2011 & 79 & 0 & $0 \%$ & No NEC observed \\
\hline Overcash & 2014 & 191 & 2 & $1 \%$ & $\begin{array}{l}\text { Early gestational age was only variable to predict } \\
\text { adverse outcomes }\end{array}$ \\
\hline De Buys & 2015 & 68 & 5 & $7.4 \%$ & Database mortality rate of $12 \%$ \\
\hline Fullerton & 2017 & 4420 & 204 & $4.6 \%$ & $\begin{array}{l}3.9 \% \text { death rate among NEC patients } \\
49 \text { surgical NEC cases }(12.2 \% \text { mortality among } \\
\text { surgical cases) }\end{array}$ \\
\hline Gupta & 2017 & 682 & 26 & $3.8 \%$ & $\begin{array}{l}\text { NEC risk associated with outborn status, } \\
\text { admission after } 2009 \text {, and CLABSI }\end{array}$ \\
\hline Current Study & 2017 & 218 & 9 & $4.1 \%$ & $\begin{array}{l}\text { NEC more common in small, pre-term infants: } \\
44 \% \text { readmitted for NEC ( } 4 \text { of } 11)\end{array}$ \\
\hline
\end{tabular}

the possibility of acute illness outside of the setting of a patient's initial hospitalization for gastroschisis repair. For those gastroschisis patients who do experience NEC as a complication, conservative management is more frequently successful as compared to $\mathrm{NEC}$ in the general neonatal population

\section{Conclusion}

The overall incidence of NEC has decreased compared to earlier reports. NEC does complicate the hospital course for patients, significantly increasing duration of in-hospital treatment. NEC in gastroschisis differs in comparison to traditional NEC, by presenting later in life. Risk factors identified for NEC in gastroschisis include low gestational age and low birth weight. Avoiding elective pre-term deliveries may decrease the rate of NEC in gastroschisis.

\section{References}

1 Soares H, Silva A, Rocha G, et al: Gastroschisis: Preterm or Term Delivery? Clinics 2010; 65 (2): 139-42.

2 Bergholz R, Moettcher M, Reinshagen K, et al. Complex gastroschisis is a different entity to simple gastroschisis affecting morbitity and mortality- A systematic review and meta-analysis. J Pediatr Surg. 2014; 49(10) 1527-1532.

3 Bell MJ, Ternberg JL, Feigin RD, et al: Neonatal necrotizing enterocolitis. Therapeutic decisions based upon clinical staging. Ann Surg 1978; 1: 1-7.

4 Oldham K T, Coran AG, Drongowski RA, et al: The development of necrotizing enterocolitis following repair of gastroschisis: a surprisingly high incidence. $J$ Pediatr Surg 1988; 10: 945-949.

5 Lao OB, Larison C, Garrison MM, et al: Outcomes in neonates with gastroschisis in U.S. children's hospitals. Am J Perinatol 2010; 1: 97-101.

6 Maramreddy H, Fisher J, Slim M, et al. Delivery of gastroschisis patients before 37 weeks of gestation is associated with increased morbidities. $J$ Pediatr Surg 2009; 44:1360

7 Charlesworth P, Njere I, Allotey J, et al. Postnatal outcome in gastroschisis: effect of birth weight and gestational age. J Pediatr Surg 2007; 42:815-818.

8 Snyder CL. Outcome Analysis for Gastroschisis. $J$ Pediatr Surg 1999; 34(8): 1253-1256.

9 Jayanthi S, Seymour P, Puntis JW, et al. Necrotizing Enterocolitis after Gastroschisis repair: a preventable complication? J Pediatr Surg 1998; 5: 705-707.

10 Kassa AM, Lilja HE. Predictors of postnatal outcome in neonates with gastroschisis. J Pediatr Surg 2011; 46: $2108-2114$ 
11 Eggink BH, Richardson CJ, Malloy MH. Outcomes of gastroschisis: a 20-year case review of infants with gastroschisis born in Galveston, Texas. J Pediatr Surg 2006; 41(6): 1103-8.

12 Fullerton BS, Velazco CS, Sparks EA, et al. Contemporary Outcomes of Infants with Gastroschisis in North America: A Multicenter Cohort Study. $J$ Pediatr 2017; Sep; 188:192-197.

13 De Buys Roessingh AS, Damphousse A, Ballabeni $\mathrm{P}$, et al. Predictive factors at birth of the severity of gastroschisis. World J Gastrointest Pathophysiol; 2015 Nov 15; 6(4):228-34.

14 Lusk LA, Brown EG, Overcash RT, et al. Multiinstitutional practice patterns and outcomes in uncomplicated gastroschisis: A report from the University of California Fetal Consortium (UCfC). $J$. Pediatr Surg 2014; 49(12): 1782-1786.

15 Overcash RT, DeUgarte DA, Stephenson ML, et al. Factors Associated With Gastroschisis outcomes. Obstet Gynecol. 2014; 124(3): 551-557.

16 Gupta R, Cabacungan ET. Outcome of neonates with gastroschisis at different gestational ages using a national database. J Pediatr Surg Online 22 July 2017

17 Arnold M. Is the incidence of gastroschisis rising in South Africa in accordance with international trend? A retrospective analysis at Pretoria Academic and Kalafong Hospitals, 1981-2001. S Afr J Surg 2004; 42(3):86-8.

18 Kazaura MR, Lie RT, Irgens LM, et al. Increasing risk of gastroschisis in Norway: an age-period-cohort analysis. Am J Epidemiol 2004; 159 (4): 358-63.

19 Laughon M, Meyer R, Bose C, et al. Rising birth prevalence of gastroschisis. J Perinatol 2003; 23 (4): 291-3.

20 Reid KP, Kickinson JE, Doherty DA. The epidemiologic incidence of congenital gastroschisis in Western Australia. Am J Obstet Gynecol 2003; 189 (3): 764-8.

21 Mastroiacoro P, Lisi A, Castilla EE. The incidence of gastroschisis: research urgently needs resources. Bmj 2006; 332 (7538): 423-4
22 Berseth CL, Malachowski N, Cohn RB, et al. Longitudinal growth and late morbidity of survivors of gastroschisis and omphalocele. J Pediatr Gastroenterol Nutr 1982; 1: 375-9.

23 Bradnock TJ, Marven S, Owen A, et al. Gastroschisis: One Year Outcomes from National Cohort Study. BM (Clinical research ed.) 2011; 343.

24 Kassa AM, Lilja HE. Predictors of postnatal outcome in neonates with gastroschisis. J Pediatr Surg 2011; 46 (11): 2108-14.

25 Coran, Arnold G., and N. Scott. Adzick. "Necrotizing Enterocolitis." Pediatric Surgery. Philadelphia, PA: Elsevier Mosby, 2012, pp 1187.

26 Houben $\mathrm{CH}$, Chan KW, Mou JW, et al. Management of Intestinal Strictures Post Conservative Treatment of Necrotizing Enterocolitis: The Long Term Outcome. $J$ Neonatal Surg. 2016 Jul 3; 5(3):28.

27 Palleri E, Aghamn I, Bexelius TS, et al. The effect of gestational age on clinical and radiological presentation of necrotizing enterocolitis.

28 Fullerton BS, Hong CR, Velazco CS, et al. Severe neurodevelopmental disability and healthcare needs among survivors of medical and surgical necrotizing enterocolitis: A prospective cohort study.

29 Langer JK. Fetal abdominal wall defects. Semin Pediatr Surg. 1993 May;2(2):121-8

30 Hoehner JC, Ein SH, Kim PC. Management of gastroschisis with concomitant jejulo-ileal atresia. $J$ Pediatr Surg. 1998 Jun;33(6):885-8.

31 Luton D, De Lagausie P, Guibourdenche J, et al. Prognostic factors of prenatally diagnosed gastroschisis. Fetal Diagn Ther. 1997 JanFeb;12(1):7-14.

32 Schlueter RK, Azarow KS, Hines AG, et al. Identifying strategies to decrease infectious complications of gastroschisis repair. J Pediatr Surg. $2015 \mathrm{Jan} ; 50(1): 98-101$

33 Gorra AS, Needelman H, Azarow KS, et al: Long-term neurodevelopmental oucomes in children born with gastroschisis: the tiebreaker. J Pediatr Surg 2012; 47: $125-129$
34 Huang J, Kurkchubaschi AG, Carr SR, et al: Benefits of Term Delivery in Infants With Antenatally Diagnosed Gastroschisis. Obstet Gynecol 2002; 4:695-699.

35 Cortez J, Makker K, Kraemer DF, et al. Maternal milk feedings reduce sepsis, necrotizing enterocolitis and improve outcomes of premature infants. $J$ Perinatol. 2017 Oct 19

36 Li YW, Yan CY, Yang L, et al. Effect of breastfeeding versus formula milk feeding on pre-term infants in the neonatal intensive care unit. Zhongguo Dang Dai Er Ke Za Zhi. 2017 May; 19(5):572-575.

37 Manea A, Boia M, Iacob D, et al. Benefits of early enteral nutrition in extremely low birth weight infants. Singapore Med J. 2016 Nov;57(11):616-618. 